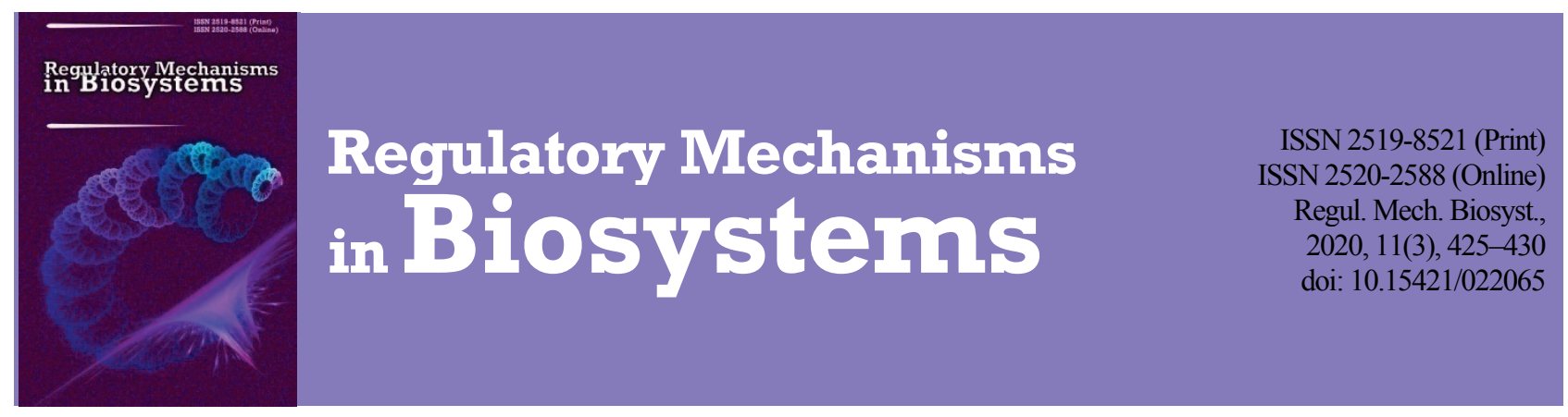

\title{
Assessment of ecological stability in yield for breeding of spring barley cultivars with increased adaptive potential
}

\author{
V. M. Hudzenko*, O. A. Demydov*, V. P. Kavunets*, L. M. Kachan**, V. A. Ishchenko***, M. O. Sardak**** \\ *The V. M. Remeslo Myronivka Institute of Wheat of National Academy of Agrarian Sciences of Ukraine, Kyiv region, Ukraine \\ **Bila Tserkva National Agrarian University, Bila Tserkva, Ukraine \\ ***Institute of Agriculture of Steppe of National Academy of Agrarian Sciences of Ukraine, Kirovohrad region, Ukraine \\ ****Nosivka Plant Breeding and Experimental Station of the V. M. Remeslo Myronivka Institute of Wheat of the National Academy \\ of Agrarian Sciences of Ukraine, Doslidne, Chernihiv region, Ukraine
}

Article info

Received 24.03.2020

Received in revised form 20.04.2020

Accepted 23.04.2020

The V. M. Remeslo Myronivka Institute of Wheat of National Academy of Agrarian Sciences of Ukraine, Tsentralna st., 68 , Tsentralne village, Myronivka district, Kyiv region, 08853, Ukraine. Tel.: +38-096879-38-00.E-mail: barley22@ukr.net

Bila Tserkva National Agrarian University, Soborna pl., 8/1, Bila Tserkva, Kyiv region, 09117, Ukraine. Tel.: +38-097-649-18-13. E-mail: viddilaspirantura@btsau.edu.ua

Institute of Agriculture of Steppe of National Academy of Agrarian Sciences of Ukraine, Tsentralna st., 2, Sozonivka village, Kirovohrad district, Kirovohrad region, 27602

Ukraine. Tel.: +38-096-994-22-45.

E-mail:semena2013@ukr.net

Nosivka Plant Breeding and Experimental Station of the V. M. Remeslo Myronivka Institute of Wheat of the National Academy of Agrarian Sciences of Ukraine, Myru st., 1

Doslidne village, Nosivka district,

Chernihiv region, 17131, Ukraine.

Tel. $+38-098-442-31-51$.

E-mail:sds11@ukr.net

\section{Introduction}

One of the most significant global problems among those facing agricultural production and science is the unprecedented growth of the world's population, which requires increasing production of the main crops by almost $100 \%$ by 2050 (Godfray et al., 2010; Tilman et al., 2011). The current dynamics in crop yield increase do not correspond to the necessary rates to ensure the parity between production and consumption (Ray et al., 2013). The solution of the problem of providing food to humanity is complicated by global climate changes (Smith \& Gregory, 2013; Moore \& Lobell, 2015). Barley (Hordeum vulgare L.) is one of the five major crops in world agriculture (Ullrich, 2011). Therefore, barley grain production augmentation, as a result of increasing the genetic potential of productivity along with its stability, is one of the priority breeding tasks. Ukraine is one of the largest producers and exporters of barley grain. However, the territory of Ukraine is characterized by significant differences between agroclimatic zones and subzones, which require special atten-
Hudzenko, V. M., Demydov, O. A., Kavunets, V. P., Kachan, L. M., Ishchenko, V. A., \& Sardak, M. O. (2020). Assessment of ecological stability in yield for breeding of spring barley cultivars with increased adaptive potential. Regulatory

Increasing crop adaptability in terms of ensuring a stable level of productivity in the genotype - environment interaction is still the central problem of plant breeding theory and practice. The aim of the present study is to theoretically substantiate and practically test a scheme of multi-environment trials, as well as interpret experimental data using modern statistical erformance and ecological stability at the final stage of the spring barley breeding process. For this purpose in the first year pe-environmental data from seven environments, which represent a combination of contrasting agroclimatic zones (agroclimatic zones) and temporal (years) gradients to identify the best spring barley genotypes with the optimal combination of yield performance and ecological stability. Using AMMI and GGE biplot models was effective for the comprehenenvironments and providing mega-environment analysis. As a practical result of the multi-environment trial, four spring barley breeding lines have been submitted to the State Variety Testing of Ukraine as new cultivars MIP Sharm, MIP Tytul,

Keywords: Hordeum vulgare; yield; multi-environment trial; additive main effects and multiplicative interaction (AMMI); genotype main effects plus genotype by environment interaction (GGE).

tion to be paid to increasing adaptability in new cultivars. As an example, under conditions of the Ukrainian Forest-Steppe, modern spring barley cultivars should be characterized with high yield potential, as well as drought tolerance, lodging resistance, and resistance to a number of the most widespread pathogens (Hudzenko et al., 2017).

Grain yield, as the main integral economic characteristic of any commercial cultivar is formed under the influence of numerous different environmental factors. Genotypes differ in the efficiency of assimilation and conversion of environmental resources into the biomass of plant organs that make up the final product - the phenotype (Malosetti et al., 2013). Genetic differences in adaptation to specific environmental conditions have been detected using molecular markers (Liviero et al., 2002). It has been proved that selection for high-input and low-input environments should be carried out purposefully with a selection and combination in the genotype of precisely those alleles and traits that contribute to yield formation under appropriate conditions (van Oosterom \& Acevedo, 1992; Ceccarelli, 1996; Pswarayi et al., 2008; von Korff et al., 2008; Anbessa et al., 
2010). It rarely happens that the ranges of vital factors of growing conditions coincide with those optimal for plants. At least one factor is limiting. Its effect on gene products (proteins - enzymes) leads to the epigenetic regulation of genes and modifies the phenotypic manifestation of quantitative traits. The presence of the epigenetic regulation of gene expression causes elementary adaptive reactions, which are stages in the chain of genotype hereditary realization and are ultimately expressed in quantitative and qualitative traits specific to it. Genotypes providing a relatively stable level phenotypic manifestation of traits in different environments are characterized by wide adaptation and high ecological stability (Zhuchenko, 1988). Genotypes prevailing only in a certain environment are specifically adapted and have low ecological stability. Specific adaptation is closely related to the genotype by environment interaction. This phenomenon is one of the central problems of plant breeding theory and practice (Hill, 1975; Zhao \& Xu, 2012). There are different situations when genotype by environment interaction occurs: divergence, convergence, and cross-over interaction (Malosetti et al., 2013). Cross-over genotype by environment interaction is the most important for breeders as it implies that the choice of the best genotype is determined by the environment. Therefore, the selection of genotypes in some conditions does not guarantee their advantage in other conditions.

Thus, the aim of the present study is to theoretically substantiate and practically test the scheme of multi-environment trials, as well as interpret experimental data using modern statistical tools for evaluation of the genotype by environment interaction, and highlight the best genotypes for combining yield performance and ecological stability at the final stage of the spring barley breeding process.

\section{Materials and methods}

Plant material and experimental design. At the first stage in competitive strain testing at the V. M. Remeslo Myronivka Institute of Wheat (MIW) of National Academy of Agrarian Sciences of Ukraine (NAAS) (Central part of the Forest-Steppe of Ukraine) in 2016 we selected nine spring barley breeding lines Nutans 4966 (GBR/Luchezarnyi), Nutans 4982 (Sebastian/Yukatan), Nutans 5069 (Bojos/Obolon), Deficiens 5145 (Celinka/Yakub), Nutans 5150 (Vivaldi/Ebson), Nutans 5152 (Vivaldi/ Ebson), Nutans 5157 (Vivaldi/Ebson), Nutans 5032 (Sozonivskyi/Celinka), Nutans 5093 (Selenit/Katrion) with a combination of valuable traits. These traits were yield performance, lodging resistance, tolerance to drought and resistance to widespread pathogens (Blumeria (Erysiphe) graminis (DC.) Golovin ex Speer f. sp. hordei Em. Marchal, Pyrenophora teres Drechs., Bipolaris sorokiniana (Sacc.) Shoem., Pyrenophora graminea Ito \& Kurib. and Puccinia hordei Otth.). During the second stage in 2017 and 2018, we investigated the promising spring barley lines in three agroclimatic zones (Central part of the Forest-Steppe, Polissia and Northern Steppe of Ukraine). For a more reliable assessment, the breeding lines were compared not only with standard cultivar Vzirets, but also with the most widespread cultivars in production conditions of Ukraine which were developed in different Ukrainian institutions: Virazh, Talisman Myronivskyi, MIP Mymyi, MIP Sotnyk (MIW); Sviatohor, Vakula (Plant Breeding and Genetics Institute - National Centre of Seed and Cultivar Investigation of NAAS), Dokaz, Alehro, Modern and Pan (The Plant Production Institute nd. a. V. Y. Yuriev of NAAS). The spring barley cultivars were sown annually in the same block of competitive testing with the breeding lines. The trial was laid out with randomized complete blocks in three replications in each agroclimatic zone. The size of the elementary plots was $10 \mathrm{~m}^{2}$.

Sites, soils and meteorological conditions description: 1) Central part of the Forest-Steppe of Ukraine. Location is MIW $\left(49^{\circ} 64^{\prime} \mathrm{N} 31^{\circ} 08^{\prime} \mathrm{E}\right.$, altitude $153 \mathrm{~m}$ ). Soils are deep, little humus, slightly leached chornozem. Humus content $3.8 \%$, alkaline hydrolysed nitrogen $-59.0 \mathrm{mg} / \mathrm{kg}, \mathrm{P}_{2} \mathrm{O}_{5}-$ $220.1 \mathrm{mg} / \mathrm{kg}, \mathrm{K}_{2} \mathrm{O}-96.0 \mathrm{mg} / \mathrm{kg}, \mathrm{pH}=5.8 ; 2$ ) Polissia region of Ukraine. Location is Nosivka Plant Breeding and Experimental Station of the V. M. Remeslo Myronivka Insitute of Wheat of NAAS (NPBES) (Distance from MIW is $240 \mathrm{~km}$ to the north $\left(50^{\circ} 93^{\prime} \mathrm{N}, 31^{\circ} 69^{\prime} \mathrm{E}\right.$, altitude 126 $\mathrm{m})$. Soils are modal, little humus, leached chernozem. Humus content $\left.2.6 \%, \mathrm{~N}-85 \mathrm{mg} / \mathrm{kg}, \mathrm{P}_{2} \mathrm{O}_{5}-122 \mathrm{mg} / \mathrm{kg}, \mathrm{K}_{2} \mathrm{O}-75 \mathrm{mg} / \mathrm{kg}, \mathrm{pH}=4.6 ; 3\right)$. Northern Steppe of Ukraine. Location is Institute of Agriculture of Steppe of NAAS (IAS); distance from MIW is $230 \mathrm{~km}$ to the south $\left(48^{\circ} 56^{\prime} \mathrm{N}\right.$, $32^{\circ} 32^{\prime} \mathrm{E}$, altitude $171 \mathrm{~m}$ ). Soils are deep, middle humus, clayic loamic chornozem. Humus content $4.6 \%, \mathrm{~N}-120 \mathrm{mg} / \mathrm{kg}, \mathrm{P}_{2} \mathrm{O}_{5}-116 \mathrm{mg} / \mathrm{kg}$, $\mathrm{K}_{2} \mathrm{O}-118 \mathrm{mg} / \mathrm{kg}, \mathrm{pH}=5.4$. Meteorological conditions during the spring barley growing season significantly differed through agroclimatic zones and years (Table 1).

\section{Table 1}

Meteorological conditions during spring barley growing season in different agroclimatic zones of Ukraine

\begin{tabular}{|c|c|c|c|c|c|c|c|c|c|}
\hline \multirow{2}{*}{ Year } & \multirow{2}{*}{ Code } & \multicolumn{4}{|c|}{ Monthly air temperature, ${ }^{\circ} \mathrm{C}$} & \multicolumn{4}{|c|}{ Monthly precipitation, $\mathrm{mm}$} \\
\hline & & April & May & June & July & April & May & June & July \\
\hline \multicolumn{10}{|c|}{$\begin{array}{l}\text { The V. M. Remeslo Myronivka Institute of Wheat of NAAS } \\
\text { (Central part of the Forest-Steppe of Ukraine) }\end{array}$} \\
\hline 16 & M16 & 12.4 & 15.2 & 20.1 & 22.2 & 55.4 & 91.7 & 68.6 & 19.1 \\
\hline & & 10.4 & & & 21 & & & & 101.8 \\
\hline & & 13.3 & & & & & & & \\
\hline 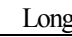 & term & 8.8 & 15.0 & 18.0 & 19.7 & 42.1 & 1.2 & 85.2 & 86.5 \\
\hline \multicolumn{10}{|c|}{$\begin{array}{l}\text { Nosivka Plant Breeding and Experimental Station } \\
\text { of the V. M. Remeslo MIW of NAAS (Polissia of Ukraine) }\end{array}$} \\
\hline 2017 & N17 & 9.5 & 13.9 & 18.6 & 19.1 & 35.4 & 44.3 & 33.0 & 109.3 \\
\hline & & 11.4 & & & & O & & & \\
\hline Long & term & 7.9 & 15.0 & 18.4 & 20.2 & 35.6 & 45.1 & 64.5 & 12 \\
\hline \multicolumn{10}{|c|}{ Institute of Agriculture of Steppe of NAAS (Northern Steppe of Ukraine) } \\
\hline 17 & & 10.9 & & & 23 & 23.5 & 10.7 & 22 & 66. \\
\hline 2010 & KI8 & 15.0 & 20. & 22.9 & 23.7 & 10.0 & 25.5 & 29.2 & \\
\hline Long & term & 8.9 & 15.3 & 18.6 & 20.0 & 36.0 & 45.0 & 66.0 & 72.0 \\
\hline
\end{tabular}

Statistical analysis. To evaluate genotype by environment interaction, genotype differentiation, and selection of breeding lines with combination of yield performance and stability we applied additive main effects and multiplicative interaction (AMMI) and genotype main effects plus genotype by environment interaction (GGE biplot) models. Both AMMI and GGE combine analysis of variance for additive parameters and singular value decomposition for multiplicative parameters, the principal components (Gauch et al., 2008). These results are graphically displayed as a biplot, first reported by Gabriel in 1971. A biplot is a scatter plot that approximates and graphically displays a two-way table by both its row and column factors such that relationships among the row factors, relationships among column factors, and the underlying interactions between the row and column factors can be visualized simultaneously. Mathematically, a biplot is regarded as a graphical display of matrix multiplication (Yan \& Tinker, 2006; Hongyu et al., 2014). Comparisons of AMMI and GGE biplot, their similarities, peculiarities and advantages have been discussed in several papers (Yan et al., 2007; Gauch et al., 2008). AMMI and GGE biplot analyses were performed when using non-commercial software GEA-R, version 4.1. Software review is provided in the publication (Frutos et al., 2014). Analysis of variance of the AMMI conducted accordingly to approach described by Gollob (1968).

\section{Results}

Spring barley genotypes yield performance. Grain yield of the spring barley gynotypes significantly varied, depending on agroclimatic zones and meteorological conditions of the year (Table 2). We noted significant differences in yield performance of the genotypes throughout all environments (zones and years combinations). The maximum yield in the environments M16 (8.25 tha) and M17 (5.35 tha) was observed for the breeding line G10, in the M18 for the breeding line G7 (3.95 tha), in the N17 for the breeding line G3 (7.09 tha), in the N18 for the cultivar G15 ( 6.45 tha), in the K17 for the cultivar G13 (4.89 tha), in the K18 for the breeding line G5 (4.06 tha). The highest mean yield was in the breeding line G7 (5.46 t/ha), the lowest mean yield was in the cultivar G17 (4.26 tha). Breeding lines G3, G4, G5, G7, and G10, as well as cultivar G13 reliably predominated in yield over the standard cultivar G1. The breeding lines G2, G6, G8, G9 and the cultivars G11, G12, G18 and G19 had a slightly higher yield than the standard cultivar G1. The cultivars G14 and G15 had yield near to the standard cultivar G1. The cultivars G16, G17 and G20 were significantly inferior in yield compared to the standard. Thus, we found significant variability of the mean yield for all tested genotypes in different environments, as well as a changing in individual geno- 
type yield ranks throughout the environments. It clearly indicates the presence of a cross-over genotype by environment interaction.

Additive main effects and multiplicative interaction. Analysis of variance of the AMMI (Gollob, 1968) showed a significant predomination of the contribution of environmental conditions to the total variation (82.8\%) (Table 3). The genotype by environment interaction percentage was $12.5 \%$, and the genotype contribution it was $4.7 \%$. Despite the last two parameters having low numerical values, they were reliable. The first two principal components of the AMMI (Factor 1, Factor 2) explained 81.1\% of the genotype by environment interaction. AMMI1 biplot (Fig. 1) allows graphic analysis of the variance of genotypes and test environments and the interaction between them. The variation of the main additive effects (mean yield) of genotypes (G1-20) and environments (M16-K18) is located on the horizontal axis (YLD). The first principal component of the multiplicative effects variation of the genotype by environment interaction is located on the vertical axis (Factor 1). The vertical line, which passes through origin of the AMMI1 biplot represents the grand mean yield in the trial (mean for all genotypes). The lines with the arrows at the end indicate the environment vectors. The vector length allows visualization of the remoteness of a certain environment from the origin of the AMMI1 biplot along the mean yield axis or the first principal component values axis.

\section{Table 2}

Grain yield (tha) of spring barley genotypes in the multi-environment trial $(\mathrm{x} \pm \mathrm{SD}, \mathrm{n}=3)$

\begin{tabular}{|c|c|c|c|c|c|c|c|c|c|}
\hline \multirow{3}{*}{ Code } & \multirow{3}{*}{$\begin{array}{c}\text { Genotype } \\
\text { (cultivar/breeding line) }\end{array}$} & \multicolumn{7}{|c|}{ Location and year of trial (code) } & \multirow{3}{*}{ Mean } \\
\hline & & \multicolumn{3}{|c|}{ MIW* } & \multicolumn{2}{|c|}{ NPBES** } & \multicolumn{2}{|c|}{ IAS*** } & \\
\hline & & 2016 (M16) & 2017 (M17) & 2018 (M18) & 2017 (N17) & 2018 (N18) & $2017(\mathrm{~K} 17)$ & $2018(\mathrm{~K} 18)$ & \\
\hline G1 & Vzirets (standard) & $6.88 \pm 0.19$ & $4.66 \pm 0.18$ & $2.90 \pm 0.15$ & $6.61 \pm 0.18$ & $4.53 \pm 0.24$ & $4.53 \pm 0.15$ & $3.25 \pm 0.05$ & $4.77 \pm 0.16$ \\
\hline G2 & Nutans 4966 & $7.61 \pm 0.14$ & $4.82 \pm 0.09$ & $3.40 \pm 0.20$ & $6.72 \pm 0.18$ & $5.01 \pm 0.22$ & $3.76 \pm 0.20$ & $3.26 \pm 0.04$ & $4.94 \pm 0.15$ \\
\hline G3 & Nutans 4982 & $8.03 \pm 0.14$ & $5.24 \pm 0.09$ & $3.75 \pm 0.09$ & $7.09 \pm 0.10$ & $5.53 \pm 0.15$ & $4.12 \pm 0.18$ & $3.54 \pm 0.13$ & $5.33 \pm 0.13$ \\
\hline G4 & Nutans 5069 & $8.01 \pm 0.19$ & $5.03 \pm 0.17$ & $3.50 \pm 0.18$ & $6.65 \pm 0.09$ & $6.28 \pm 0.21$ & $4.39 \pm 0.11$ & $3.01 \pm 0.10$ & $5.27 \pm 0.15$ \\
\hline G5 & Deficiens 5145 & $7.54 \pm 0.10$ & $5.09 \pm 0.21$ & $2.70 \pm 0.02$ & $6.79 \pm 0.08$ & $5.40 \pm 0.16$ & $4.81 \pm 0.36$ & $4.06 \pm 0.15$ & $5.20 \pm 0.15$ \\
\hline G6 & Nutans 5150 & $7.99 \pm 0.17$ & $4.91 \pm 0.14$ & $3.34 \pm 0.21$ & $6.19 \pm 0.17$ & $5.42 \pm 0.23$ & $4.83 \pm 0.19$ & $2.37 \pm 0.04$ & $5.01 \pm 0.16$ \\
\hline G7 & Nutans 5152 & $8.13 \pm 0.17$ & $5.06 \pm 0.10$ & $3.95 \pm 0.09$ & $6.49 \pm 0.13$ & $6.20 \pm 0.23$ & $4.34 \pm 0.17$ & $4.07 \pm 0.06$ & $5.46 \pm 0.14$ \\
\hline G8 & Nutans 5157 & $7.83 \pm 0.07$ & $4.88 \pm 0.11$ & $2.89 \pm 0.13$ & $5.82 \pm 0.18$ & $5.31 \pm 0.15$ & $3.97 \pm 0.25$ & $3.46 \pm 0.14$ & $4.88 \pm 0.15$ \\
\hline G9 & Nutans 5032 & $7.89 \pm 0.06$ & $4.63 \pm 0.10$ & $3.04 \pm 0.09$ & $6.50 \pm 0.16$ & $5.26 \pm 0.25$ & $3.60 \pm 0.12$ & $2.96 \pm 0.03$ & $4.84 \pm 0.12$ \\
\hline G10 & Nutans 5093 & $8.25 \pm 0.10$ & $5.35 \pm 0.08$ & $3.76 \pm 0.08$ & $6.94 \pm 0.17$ & $5.75 \pm 0.28$ & $4.06 \pm 0.07$ & $2.99 \pm 0.15$ & $5.30 \pm 0.12$ \\
\hline G11 & Virazh & $7.13 \pm 0.25$ & $5.08 \pm 0.09$ & $3.34 \pm 0.12$ & $7.01 \pm 0.12$ & $4.66 \pm 0.16$ & $3.81 \pm 0.26$ & $2.99 \pm 0.06$ & $4.86 \pm 0.15$ \\
\hline G12 & Talisman Myronivskyi & $7.05 \pm 0.13$ & $4.97 \pm 0.14$ & $3.15 \pm 0.13$ & $7.02 \pm 0.08$ & $5.22 \pm 0.31$ & $4.34 \pm 0.28$ & $2.57 \pm 0.09$ & $4.90 \pm 0.17$ \\
\hline G13 & MIP Myrnyi & $7.41 \pm 0.14$ & $5.23 \pm 0.09$ & $3.77 \pm 0.04$ & $7.08 \pm 0.09$ & $5.38 \pm 0.37$ & $4.89 \pm 0.21$ & $3.22 \pm 0.15$ & $5.28 \pm 0.16$ \\
\hline G14 & MIP Sotnyk & $7.22 \pm 0.20$ & $4.83 \pm 0.19$ & $3.38 \pm 0.17$ & $6.49 \pm 0.13$ & $4.82 \pm 0.47$ & $3.46 \pm 0.14$ & $3.10 \pm 0.08$ & $4.76 \pm 0.20$ \\
\hline G15 & Sviatohor & $4.47 \pm 0.16$ & $4.53 \pm 0.38$ & $3.08 \pm 0.17$ & $6.13 \pm 0.27$ & $6.45 \pm 0.22$ & $4.79 \pm 0.21$ & $3.68 \pm 0.17$ & $4.73 \pm 0.23$ \\
\hline G16 & Vakula & $5.81 \pm 0.17$ & $4.55 \pm 0.50$ & $2.79 \pm 0.15$ & $6.11 \pm 0.28$ & $4.15 \pm 0.22$ & $4.75 \pm 0.14$ & $2.10 \pm 0.03$ & $4.32 \pm 0.21$ \\
\hline G17 & Dokaz & $6.08 \pm 0.37$ & $4.64 \pm 0.36$ & $2.28 \pm 0.16$ & $6.84 \pm 0.13$ & $3.60 \pm 0.28$ & $4.23 \pm 0.28$ & $2.13 \pm 0.06$ & $4.26 \pm 0.23$ \\
\hline G18 & Alehro & $5.08 \pm 0.20$ & $4.63 \pm 0.24$ & $2.84 \pm 0.06$ & $6.95 \pm 0.22$ & $6.22 \pm 0.26$ & $4.32 \pm 0.09$ & $3.77 \pm 0.07$ & $4.83 \pm 0.16$ \\
\hline G19 & Pan & $5.85 \pm 0.25$ & $4.54 \pm 0.43$ & $3.46 \pm 0.14$ & $6.95 \pm 0.25$ & $5.96 \pm 0.41$ & $4.04 \pm 0.37$ & $3.37 \pm 0.07$ & $4.88 \pm 0.27$ \\
\hline G20 & Modem & $4.31 \pm 0.23$ & $4.64 \pm 0.21$ & $2.72 \pm 0.14$ & $6.20 \pm 0.13$ & $5.14 \pm 0.33$ & $4.34 \pm 0.06$ & $2.76 \pm 0.16$ & $4.30 \pm 0.18$ \\
\hline
\end{tabular}

Note: * - The V. M. Remeslo Myronivka Institute of Wheat of NAAS, ** - Nosivka Plant Breeding and Experimental Station of the V. M. Remeslo MIW of NAAS, *** - Institute of Agriculture of Steppe of NAAS.

\section{Table 3}

AMMI model analysis of variance (Golob's test) of yield of the spring barley genotypes and sum of squares decomposition of the genotype by environment interaction

\begin{tabular}{lrrrc}
\hline $\begin{array}{c}\text { Source } \\
\text { of variation }\end{array}$ & $\begin{array}{r}\text { Sum of } \\
\text { squares }\end{array}$ & $\begin{array}{c}\text { Degree of } \\
\text { freedom }\end{array}$ & $\begin{array}{r}\text { Mean } \\
\text { square }\end{array}$ & $\begin{array}{c}\text { Percentage relative } \\
\text { to the sum of squares }\end{array}$ \\
\hline Genotype $(\mathrm{G})$ & 46.00 & 19 & 2.42 & $4.7^{* *}$ \\
Environment $(\mathrm{E})$ & 816.79 & 6 & 136.13 & $82.8^{* *}$ \\
G× E interaction & 123.08 & 114 & 1.08 & $12.5^{* *}$ \\
Factor 1* & 75.18 & 24 & 3.13 & $61.1^{* *}$ \\
Factor 2 & 24.63 & 22 & 1.12 & $20.0^{* *}$ \\
Factor 3 & 10.75 & 20 & 0.54 & $8.7^{* *}$ \\
Factor 4 & 8.47 & 18 & 0.47 & $6.9^{* *}$ \\
Factor 5 & 2.88 & 16 & 0.18 & 2.3 \\
Factor 6 & 1.17 & 14 & 0.08 & 1.0 \\
Factor 7 & 0.00 & 12 & 0.00 & - \\
Residuals & 9.55 & 280 & 0.03 & - \\
\hline
\end{tabular}

Note: *-Factor 1-7-principal components, ${ }^{* *}$ - significant at $1 \%$ probability level.

The environment M16 had maximum distance from the biplot origin. The environments M16 and N17 were the most productive, and the environments K18 and M18 were the least productive. The more desirable are genotypes with high productivity and located closer to zero along the vertical axis. In our case genotypes can be divided into several groups: 1) genotypes that had higher yield performance than mean yield in the trial and combined it with a high stability (G5, G13, G4, G3, G7 and G10); 2) genotypes with yield performance close to the mean yield in the trial and with relatively high stability (G12, G1, G11, G14, G2, G8, G9, G6 and G19); 3) genotypes with yield performance close to the mean yield in the trial and with high variability (G18 and G15); 4) genotypes that had poor yield performance but had relative high stability (G17 and G16); 5) the genotype G20 that had yield lower than mean yield in trial and combined it with maximal variability.
The AMMI2 biplot (Fig. 2) displays the multiplicative effects of genotype by environment interaction in the coordinates of the first (Factor 1) and second (Factor 2) principal components. It is possible to visualize dispersion of the genotypes and environments in the principal component coordinates. Genotypes that shifted from the origin of the AMMI2 biplot towards the specific environment have a stronger positive reaction to its conditions. The stable genotypes throughout environments should be located as close as possible to the origin of the AMMI2 biplot. Accordingly, the breeding line G5 had the highest stability, and the cultivars G15 and G17 were the most variable.

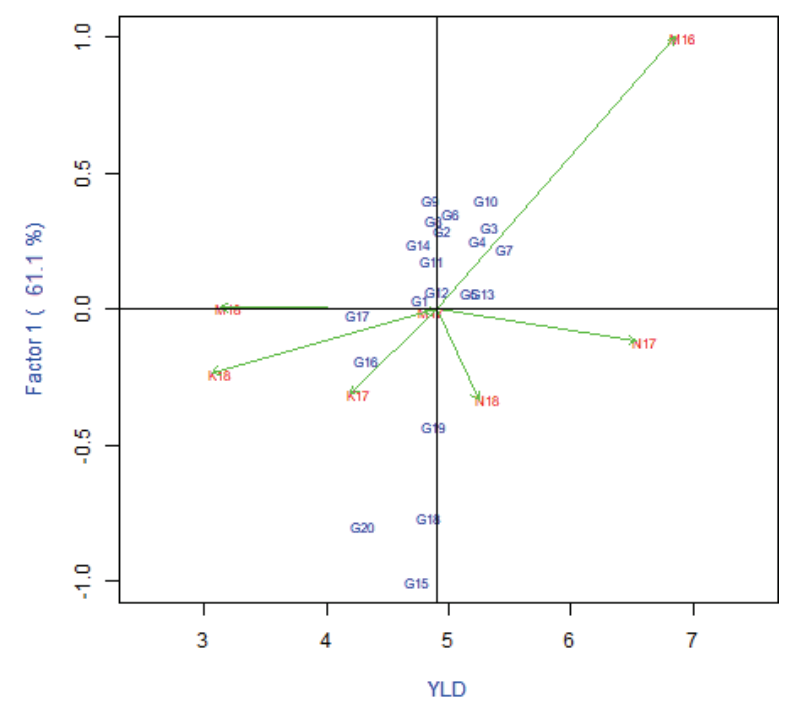

Fig. 1. The AMMI1 biplot dispersion of spring barley genotypes and test environments in coordinates of mean yield (YLD) and the first principal component (Factor 1) 
Genotype main effects plus genotype by environment interaction. Figure 3 shows the representativeness and discriminating power of environments according to the GGE biplot. The first two principal components (axis 1 and axis 2) explained $81.6 \%$ of the genotype by environment interaction. The line that intersects the biplot origin is the average environment axis (AEA). The average environment is represented on the AEA with a small circle at the end of the arrow. The dashed lines indicate the vectors of individual test environments. The length of the vector characterizes the discriminating power of an environment. Particularly, the environment M16 had the longest vector, and accordingly, it was characterized by the highest discriminating power. The lowest discriminating power was in the environment N17. The angle between an environment vector and the AEA shows its representativeness. A test environment that has smaller angle with AEA is more representative than other test environments. Thus, the highest representativeness was in the environment M18, the vector of which coincided with the AEA. The environments M16 and K17 were the most distant from each other, as is evidenced by the largest angle between their vectors. The environments N17 and M17, as well as K18 and N18 were more similar to each other, since they had the smallest angle between their vectors.

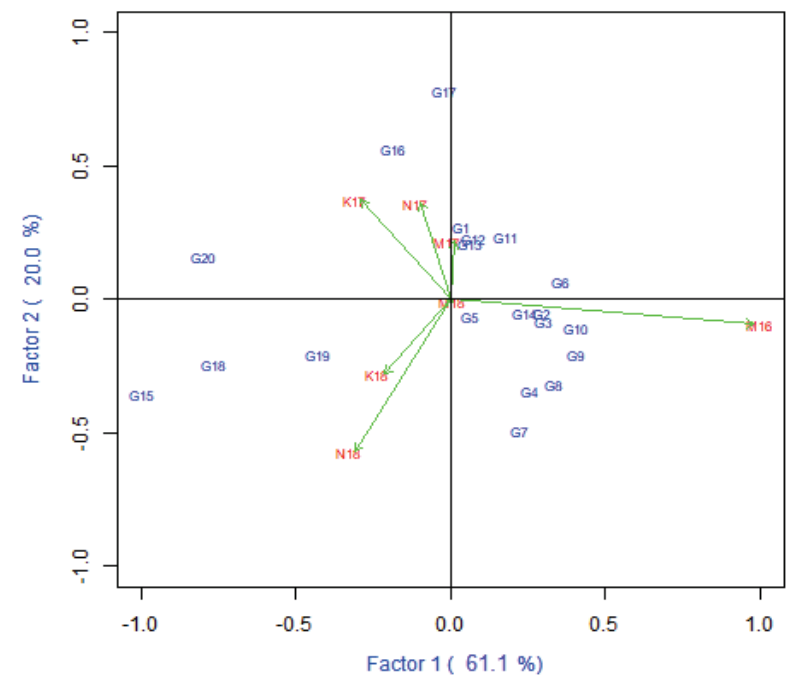

Fig. 2. The AMMI2 biplot dispersion of spring barley genotypes and test environments in coordinates of the first two principal components (factor 1 vs factor 2)

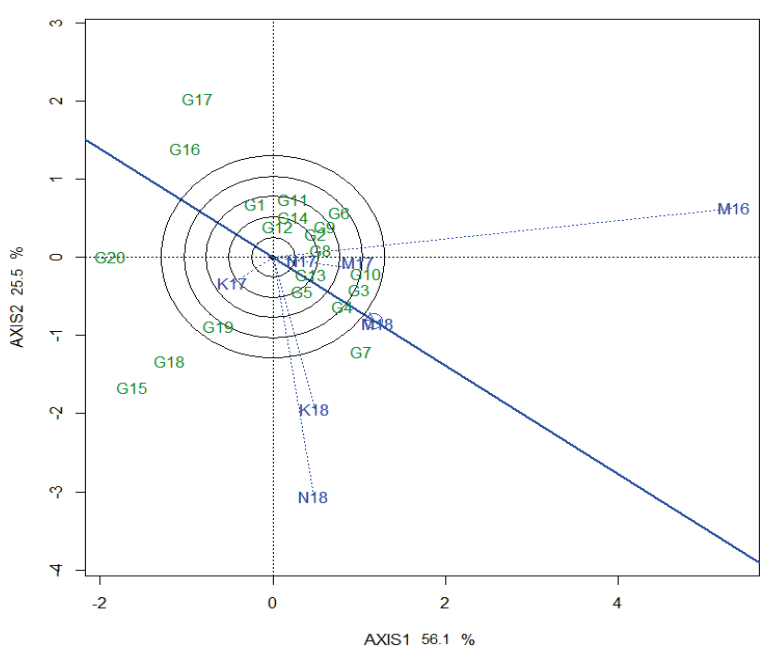

Fig. 3. GGE biplot discriminating power and representativeness of test environments

The GGE biplot "which-won-where" polygon view is an effective tool to visualize the interaction patterns between genotypes and environments (Fig. 4). The polygon is formed by connecting the genotypes that are farthest away from the origin of GGE biplot, such that all other genotypes are included within the polygon. A set of perpendiculars to each side of the polygon lines divide the GGE biplot into several sectors. The sectors at the vertex of the polygon contain genotypes that have an advantage in a single environment or in a set of environments (mega-environment).

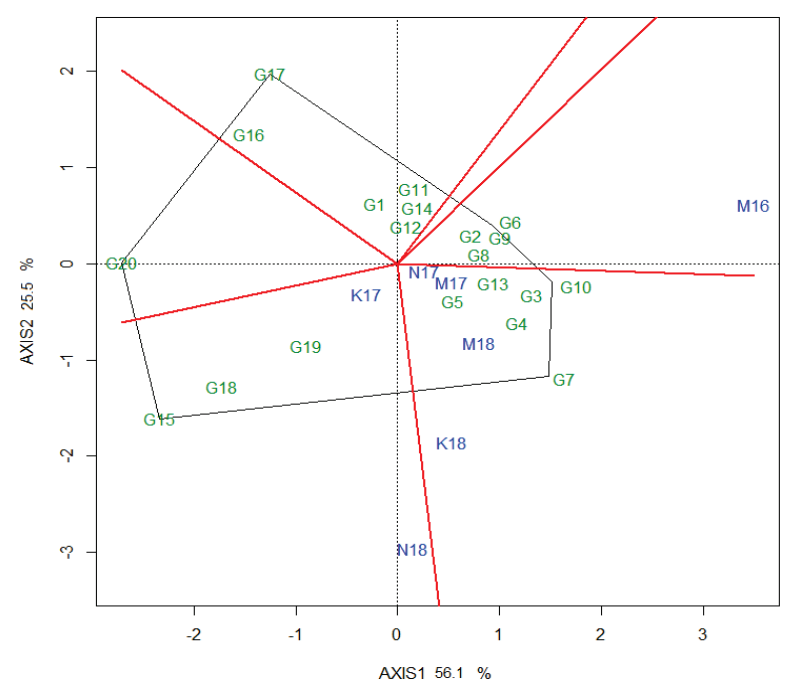

Fig. 4. GGE biplot "which-won-where" view

In our study, three sectors contained both environments and genotypes. The first mega-environment included four environments N17, M17, M18 and K18. The breeding line G7 had advantage in it. Breeding lines G10, G3, G4, G5 and cultivar G13 were also located in the first megaenvironment. The second sector included only the environment M16 and breeding lines G6, G9, G2 and G8. It should be noted that the breeding line G10, which was in the first mega-environment, also aspired towards the environment M16, since this breeding line had the highest productivity in this environment. However, the high yield performance in the individual environments that formed the first mega-environment determines the localization of the breeding line G10 exactly in it. The third mega-environment combined the conditions K17 and N18 environments. The cultivar G15 had an advantage in this mega-environment. Cultivars G18 and G19 were located in the third mega-environment also. The standard cultivar G1, as well as the cultivars G11, G12, G14, G16, G17 and G20 had poorer performance compared to the above mentioned genotypes and they were in sectors that did not contain environments.

Figure 5 shows the average environment coordination of breeding lines in terms of mean yield and stability. The line which intersects the origin of the GGE biplot from left to right is the AEA for the environments. In the direction marked with an arrow in the small circle on the abscissa, the genotypes are ranked accordingly to mean yield, however, not in tons per hectare, but in the principal components values.

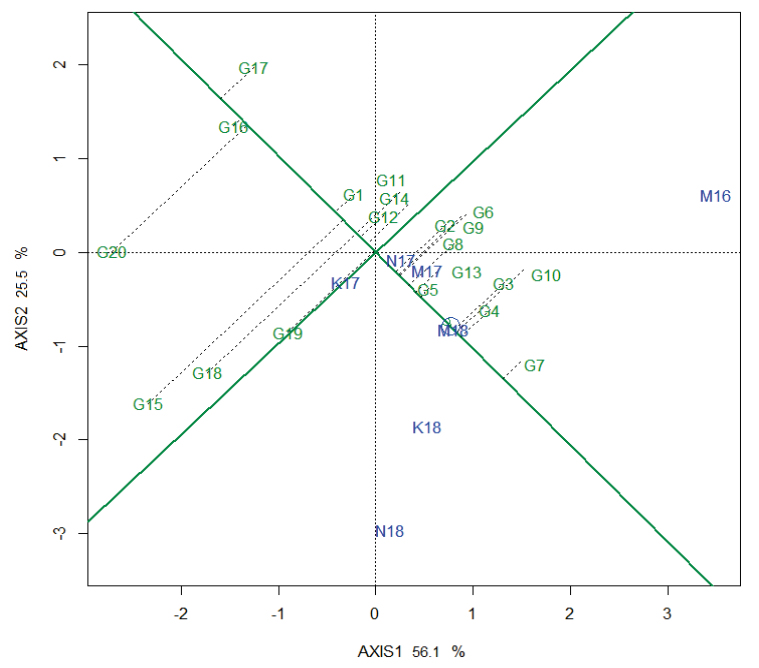

Fig. 5. The average-environment coordination view of the GGE biplot "mean yield against stability" 
The AEA intersects in the GGE biplot origin with the average ordinate The intersection point represents the mean yield of the experiment (grand mean). In our research, the breeding line $\mathrm{G} 7$ had the highest yield performance, and the cultivar G17 had the poorest one. The breeding lines G4, G3, G10, G5, G8, G9, G2, G6 and the cultivar G13 exceeded the grand mean yield in trial also. The breeding line G5 and the cultivar G16 had the highest stability, as was evidenced by their minimal deviation from the abscissa. However, the cultivar G16 was significantly inferior to most of genotypes in yield performance. Cultivars G15, G18, G20 and G19 had strong variability. The breeding line G7 had optimal combination yield performance and stability throughout test environments. Accordingly, this breeding line was as close as possible to the "ideal" genotype, which should conditionally be in the centre of centric circles (Fig. 6).

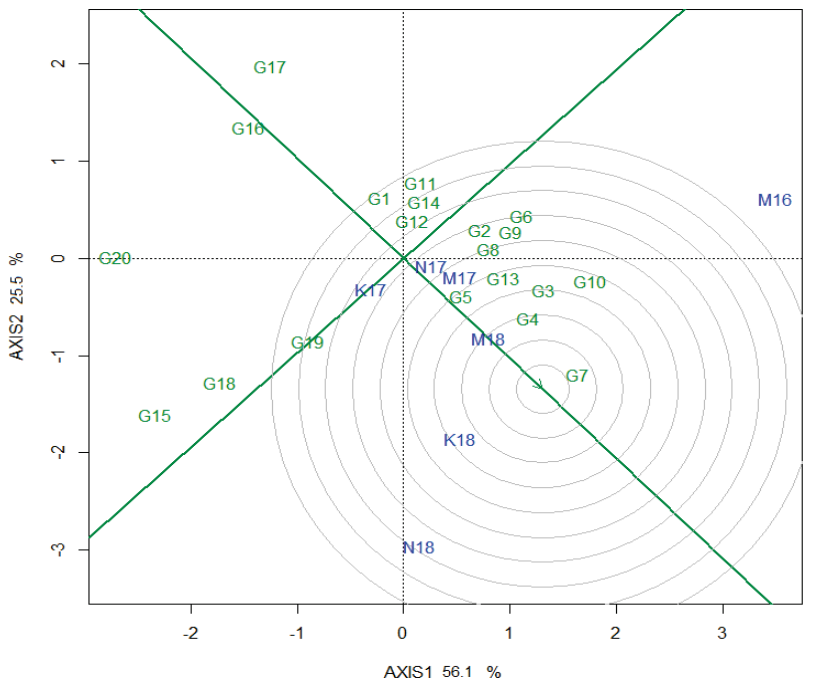

Fig. 6. GGE biplot ranking spring barley genotypes based on both mean performance and stability with reference to the "ideal" genotype

Breeding lines G4, G3, G10 and the cultivar G13 were slightly inferior to the breeding line G7 in mean yield and stability. The breeding line G5 was inferior to the G7 only in yield performance. The breeding lines G8, G2, G9 and G6 formed a cluster of genotypes which had lower yield and stability in comparison with the above mentioned genotypes, but at the same time prevailed over the majority other genotypes.

\section{Discussion}

It should be mentioned that several other researchers have also reported high year to year, or site to site grain yield variation in spring barley genotypes in Eastern European conditions (Pržulj \& Momčilović, 2012; Mirosavljević et al., 2014; Pržulj et al., 2015) and in particular in Ukraine (Solonechnyi et al., 2015; Marukhnyak, 2018). Thus, testing genotypes in various environmental conditions (multi-environment trial) is effective for assessment of genotype by environment interactions and selecting desirable ones. For interpretation of experimental data from multi-environment trials it is necessary to use the most appropriate statistical models (van Eeuwijk et al., 2016). AMMI (Mehari et al., 2014; Abtew et al., 2015; Bocianowski et al., 2019; Verma et al., 2019) and GGE biplots (Bilgin et al., 2018; Al-Ghzawi et al., 2019; Al-Sayaydeh et al., 2019; Gudzenko, 2019) have been the most widely used in recent years in order to interpret the experimental data from genotype by environmental trials. A number of researchers combine both of these statistical tools (Vaezi et al., 2017; Fana et al., 2018; Solonechnyi et al., 2018; Kendal et al., 2019). It has been shown that AMMI as well as GGE biplot explain the significantly higher percentage of genotype by environment interaction compared to other statistical methods (Namorato et al., 2009; Pereira et al., 2011). In our study, the first two principal components AMMI and GGE biplot explained more than $80 \%$ of the genotype by environment interaction. Thus, both graphical models used sufficiently contributed to the in-depth visual analysis of the experimental data from the multi-environmental trial and allowed us to provide effective differentiation of genotypes in terms of wide and specific adaptation. In addition, the GGE biplot has a number of different functions for comprehensive assessment of test environments and providing mega-environment analysis (Yan et al., 2007).

Summarizing the environment characteristics in representativeness and discriminating power according to GGE biplot, we should note both the similarities between different agroclimatic conditions (N17 and M17, $\mathrm{K} 18$ and N18), as well as differences in the same agroclimatic conditions in different years (N17 and N18, M16 and M18). In addition, the considered environments had a different level of productivity. This indicates that not only does the environments' mean productivity characterize their similarities or differences in terms of discriminating power and representativeness, but also the genotypes' ranking in yield performance. In other words, the mode of reaction of the studied genotypes influenced the statistical characteristics of the test environments. The GGE biplot "whichwon-where" visualization also demonstrates that mega-environments were formed with a combination of different environmental conditions (agroclimatic zones) and years of the trial: I - N17, M17, M18 and K18; II - M16; III- K17 and N18. This is since even at the same ecological niche, the genotypes reacted differently to changes in weather conditions in different years. Experimental data are consistent with the prevalence of environmental conditions (82.8\%) in the total dispersion and significant effect of the genotype by environment interaction (12.5\%). The low share of the genotype contribution (4.7\%) to the total dispersion, in our opinion is because only the best breeding lines and cultivars were involved in the experiment. At the same time, since the genotype contribution was reliable, this indicates the validity of the proposed combination of spatial (zones) and temporal (years) gradients for more efficient differentiation and selection of the best of the best genotypes at the final stage of spring barley breeding process. It is demonstrated that even among of three lines G6 (Nutans 5150), G7 (Nutans 5152) and G8 (Nutans 5157) selected from one crossbreeding combination (Vivaldi/Ebson), the line G7 (Nutans 5152) was significantly superior the others. Difference in the adaptive reactions among these lines was expressed by different yield performance in different environments, which was clearly shown with AMMI and GGE biplot analysis. That is, due to genetic recombination, genotypes with significantly different reactions to environmental conditions could be formed even from one crossbreeding combination. Therefore, after a detailed study of the genetic source material and successful selection of parent components for crossing, the main aim of the breeder in the subsequent breeding process is to identify such genotypes.

In general, we determined that all studied promising breeding lines exceeded the widespread cultivars in production conditions in yield performance and, in most cases, in stability. Only the spring barley cultivar MIP Myrnyi (G13) was the exception. The best spring barley breeding lines in yield performance and stability combination Nutans 5152 (G7), Nutans 5069 (G4), Nutans 4982 (G3) and Nutans 5093 (G10) were selected for further investigation in the State Variety Testing of Ukraine.

\section{Conclusion}

We developed an effective approach for organizing multi-environment trials at the final stage of breeding process which contribute to an indepth assessment of the genotype by environment interaction and differentiation of genotypes in terms of yield performance and ecological stability. The main aspects of the proposed approach are: 1) Promising breeding lines highlighted by the results in the first year of the competitive test at the MIW in the next two years are also tested in two other research institutions (NPBES and IAS). Thus, for three years of competitive testing, the genotypes are evaluated in seven environments, which represent a combination of contrasting agroclimatic zones and different years (three years in MIW (Central part of the Forest-Steppe of Ukraine) + two years in NPBES (Polissia of Ukraine) + two years in IAS (Northern Steppe of Ukraine)). Furthermore, MIW is an ecological niche where the breeding lines selected have multiyear representation in the total multi-environment trial. 2) Breeding lines are compared not only with the standard, but also with the other cultivars widespread in production conditions. It allows us to select only the best genotypes for growing in certain production conditions. 3) The experimental data from the genotype by environmental testing are analysed using AMMI and GGE biplot, which contribute to the comprehensive differentiation of genotypes in terms of wide and specific 
adaptability. In addition, these statistical tools make possible the most qualitative characterization of test environments and provide megaenvironment analysis. As a practical result of the multi-environment trial in 2016-2018 spring barley breeding lines with the optimal combination of yield performance and ecological stability, Nutans 5152, Nutans 5069, Nutans 4982 and Nutans 5093 as new cultivars MIP Sharm, MIP Tytul, MIP Deviz and MIP Zakhysnyk respectively, have been submitted to the State Variety Testing of Ukraine.

\section{References}

Abtew, W. G., Lakew, B., Haussmann, B. I. G., \& Schmid, K. J. (2015). Ethiopian barley landraces show higher yield stability and comparable yield to improved varieties in multi-environment field trials. Joumal of Plant Breeding and Crop Science, 7(8), 275-291.

Al-Ghzawi, A. L. A., Al-Ajlouni, Z. I., Al Sane, K. O., Bsoul, E. Y., Musallam, I., Khalaf, Y. B., Al-Hajaj, N., Al-Tawaha, A. R., Aldwairi, Y., \& Al-Saqqar, H. (2019). Yield stability and adaptation of four spring barley (Hordeum vulgare L.) cultivars under rainfed conditions. Research on Crops, 20(1), 10-18.

Al-Sayaydeh, R., Al-Bawalize, A., Al-Ajlouni, Z., Akash, M. W., Abu-Elenein, J., \& Al-Abdallat, A. M. (2019). Agronomic evaluation and yield performance of selected barley (Hordeum vulgare L.) landraces from Jordan. International Journal of Agronomy, 2019, 9575081.

Anbessa, Y., Juskiw, P., Good, A., Nyachiro, J., \& Helm, J. (2010). Selection efficiency across environments in improvement of barley yield for moderately low nitrogen environments. Crop Science, 50(2), 451-457.

Bilgin, O., Balkan, A., Korkut, Z. K., \& Başer, İ. (2018). Multi-environmental evaluation of triticale, wheat and barley genotypes by GGE biplot analysis. Journal of Life Sciences, 12, 13-23.

Bocianowski, J., Warzecha, T., Nowosad, K., \& Bathelt, R. (2019). Genotype by environment interaction using AMMI model and estimation of additive and epistasis gene effects for 1000-kernel weight in spring barley (Hordeum vulgare L.). Journal of Applied Genetics, 60, 127-135.

Ceccarelli, S. (1996). Adaptation to low/high input cultivation. Euphytica, 92(1-2), 203-214.

Fana, G., Tadese, D., Sebsibe, H., \& Verma, R. P. S. (2018). Multi-environment tria analysis of food barley in Ethiopia using AMMI and GGE biplot methods. Journal of Plant Breeding and Genetics, 6(3), 75-85.

Frutos, E., Galindo, M. P., \& Leiva, V. (2014). An interactive biplot implementation in R for modeling genotype-by-environment interaction. Stochastic Environmental Research and Risk Assessment, 28, 1629-1641.

Gabriel, K. R. (1971). The biplot graphic display of matrices with application to principal component analysis. Biometrica, 58(3), 453-467.

Gauch, H. G., Piepo, H.-P., \& Annicchiarico, P. (2008). Statistical analysis of yield trials by AMMI and GGE: Further consideration. Crop Science, 48(3), 866-889.

Godfray, H. C. J., Beddington, J. R., Crute, I. R., Haddad, L., Lawrece, D., Muir, J. F., Pretty, J., Robinson, S., Thomas, S. M., \& Toulmin, C. (2010). Food security: The challenge of feeding 9 billion people. Science, 327(5967), 812-818.

Gollob, H. F. (1968). A statistical model which combines feature of factor analytic and analysis of variance techniques. Psychometrika, 33, 73-115.

Gudzenko, V. N. (2019). Statisticheskaya i graficheskaya (GGE biplot) ocenka adaptivnoj sposobnosti i stabilnosti selekcionnyh linij yachmenya ozimogo [Statistical and graphical (GGE biplot) evaluation of the adaptive ability and stability of winter barley breeding lines]. Vavilov Journal of Genetics and Breeding, 23(1), 110-118 (in Russian).

Hill, J. (1975). Genotype-environment interaction - a challenge for plant breeding. The Journal of Agricultural Science, 85(3), 477-493.

Hongyu, K., Garcia-Pena, M., de Araujo, L. B., \& dos Santos Dias, C. T. (2014). Statistical analysis of yield trials by AMMI analysis of genotype $\mathrm{x}$ environment interaction. Biometrical Letters, 51(2), 89-102.

Hudzenko, V. M., Vasylkivskyi, S. P., Demydov, O. A., Polishchuk, T. P., \& Babiy, O. O. (2017). Selektsiia yachmeniu yaroho na pidvyshchennia produktyvnoho ta adaptyvnoho potentsialu [Spring barley breeding for increase in productive and adaptive capacities]. Plant Breeding and Seed Production, 111, 51-61 (in Ukrainian).

Kendal, E., Karaman, M., Tekdal, S., \& Doğan, S. (2019). Analysis of promising barley (Hordeum vulgare L.) lines performance by AMMI and GGE biplot in multiple traits and environment. Applied Ecology and Environmental Research, $17(2), 5219-5233$.

Liviero, L., Maestri, E., Gulli, M., Nevo, E., \& Marmiroli, N. (2002). Ecogeographic adaptation and genetic variation in wild barley, application of molecular markers targeted to environmentally regulated genes. Genetic Resources and Crop Evolution, 49(2), 133-144.
Malosetti, M., Ribaut, J.-M., \& van Eeuwijk, F. A. (2013). The statistical analysis of multi-environment data: modeling genotype-by-environment interaction and its genetic basis. Frontiers in Physiology, 4, 44.

Marukhnyak, A. Y. (2018). Ocenka adaptivnyh osobennostej sortov yarovogo yachmenya [Evaluation of adaptive ability of spring barley varieties]. Bulletin of the Belarussian State Agricultural Academy, 1, 67-72 (in Russian).

Mehari, M., Alamerew, S., \& Lakew, B. (2014). Genotype × environment interaction and yield stability of malt barley genotypes evaluated in Tigray, Ethiopia using the AMMI analysis. Asian Journal of Plant Sciences, 13(2), 73-79.

Mirosavljević, M., Pržulj, N., Boćanski, J., Stanisavljević, D., \& Mitrović, B. (2014). The application of AMMI model for barley cultivars evaluation in multi-year trials. Genetika, 46, 445-454.

Moore, F. C., \& Lobell, D. B. (2015). The fingerprint of climate trends on European crop yields. Proceedings of the National Academy of Sciences of the United States of America, 112(9), 2670-2675.

Namorato, H., Miranda, G. V., de Souza, L. V., Oliviera, L. R., DeLima, R. O., \& Mantovani, E. E. (2009). Comparing biplot multivariate analyses with Eberhart and Russell' method for genotype $\times$ environment interaction. Crop Breeding and Applied Biotechnology, 9(4), 299-307.

Pereira, D. G., Rodrigues, P. C., Mejza, S., \& Mexia, J. T. (2012). A comparison between joint regression analysis and the AMMI model: A case study with barley. Journal of Statistical Computation and Simulation, 82(2), 193-207.

Pržulj, N., \& Momčilović, V. (2012). Spring barley performances in the Pannonian zone. Genetika, 44, 499-512.

Pržulj, N., Mirosavljević, M., Čanak, P., Zorić, M., \& Boćanski, J. (2015). Evaluation of spring barley performance by biplot analysis. Cereal Researh Communications, 43(4), 692-703.

Pswarayi, A., van Eeuwijk, F. A., Ceccarelli, S., Grando, S., Comadran, J., Russell, J. R., Pecchioni, N., Tondelli, A., Akar, T., Al-Yassin, A., Benbelcacem, A., Ouabbou, H., Thomas, W. T. B., \& Romagosa, I. (2008). Changes in allele frequencies in landraces, old and modern barley cultivars of marker loci close to QTL for grain yield under high and low input conditions. Euphytica, 163(3), 435-447.

Ray, D. K., Mueller, N. D., West, P. C., \& Foley, J. A. (2013). Yield trends are insufficient to double global crop production by 2050 . PLoS One, 8(6), e66428.

Smith, P., \& Gregory, P. J. (2013). Climate change and sustainable food production. Proceedings of the Nutrition Society, 72(1), 21-28.

Solonechnyi, P., Kozachenko, M., Vasko, N., Gudzenko, V., Ishenko, V., Kozelets, G., Usova, N., Logvinenko, Y., \& Vinukov, A. (2018). AMMI and GGE biplot analysis of yield performance of spring barley (Hordeum vulgare L.) varieties in multi environment trials. Agriculture and Forestry, 64(1), 121-132.

Solonechnyi, P., Vasko, N., Naumov, A., Solonechnaya, O., Vazhenina, O., Bondareva, O., \& Logvinenko, Y. (2015). GGE biplot analysis of genotype by environment interaction of spring barley varieties. Zemdirbyste-Agriculture, 102(4), 431-436.

Tilman, D., Balzer, C., Hill, J., \& Befort, B. L. (2011). Global food demand and the sustainable intensification of agriculture. Proceedings of the National Academy of Sciences of the United States of America, 108(50), 20260-20264.

Ullich, S. E. (Ed.). (2011). Barley: Production, improvement, and uses. WileyBlackwell, Chichester

Vaezi, B., Pour-Aboughadareh, A., Mohammadi, R., Armion, M., Mehraban, A., Hossein-Pour, T., \& Dorii, M. (2017). GGE biplot and AMMI analysis of barley yield performance in Iran. Cereal Research Communication, 45(3), 500-511.

van Eeuwijk, F. A., Bustos-Korts, D. V., \& Malosetti, M. (2016). What should students in plant breeding know about the statistical aspects of genotype $\times$ environment interactions? Crop Science, 56(5), 2119-2140.

van Oosterom, E. J., \& Acevedo, E. (1992). Adaptation of barley (Hordeum vulgare L.) to harsh Mediterranean environments III. Plant ideotype and grain yield. Euphytica, 62(1), 29-38.

Verma, A., Kumar, V., Kharab, A. S., \& Singh, G. P. (2019). AMMI model to estimate $\mathrm{G} \times \mathrm{E}$ for grain yield of dual purpose barley genotypes. International Journal of Current Microbiology and Applied Sciences, 8(5), 1-7.

von Korff, M., Grando, S., Del Greco, A., This, D., Baum, M., \& Ceccarelli, S. (2008). Quantitative trait loci associated with adaptation to Mediterranean dryland conditions in barley. Theoretical and Applied Genetics, 117(5), 653-669.

Yan, W., \& Tinker, N. A. (2006). Biplot analysis of multi-environment trial data: Principles and applications. Canadian Journal of Plant Science, 86(3), 623-645.

Yan, W., Kang, M. S., Ma, B., Woods, S., \& Cornelius, P. L. (2007). GGE biplot vs. AMMI analysis of genotype-by-environment data. Crop Science, 47, 641-653.

Zhao, F., \& Xu, S. (2012). Genotype by environment interaction of quantitative traits: A case study in barley. G3, Genes, Genomes, Genetics, 2(7), 779-788.

Zhuchenko, A. A. (1988). Adaptivnyj potencial kulturnyh rastenij (ekologo-geneticheskie osnovy) [Adaptive potential of cultivated plants (genetic and ecological bases)]. Shtiintsa Publishers, Kishinev (in Russian). 